Notes

\title{
Sovereignty, Referenda, and the Entrenchment of a United Kingdom Bill of Rights
}

\author{
Anupam Chander
}

If a bill of rights were passed in the United Kingdom in $1992,{ }^{1}$ could Parliament pass a Bill of Rights Repeal Act the following year? The principle of parliamentary sovereignty - that "Parliament has the right to make or unmake any law whatever" to pass a repeal act and, a fortiori, any lesser act partially contravening the

1. "Bill of rights" is used here to refer to a charter guaranteeing fundamental legal rights. Current United Kingdom law includes no such comprehensive document. The Bill of Rights of 1689 guarantees only such basic rights as the right to petition, freedom from excessive bail and from cruel and unusual punishment, and the right to the due impaneling of jurors. An Act for Declaring the Rights and Liberties of the Subject, and Settling the Succession of the Crown, 1 W. \& M., ch. 36 (1689) (Eng.). The Bill of Rights of 1689 even discriminates on religious grounds. Id. at pt. IX (barring Catholics from accession to Crown). The European Convention on Human Rights is enforceable only in Strasbourg, not in domestic U.K. courts. Convention for the Protection of Human Rights and Fundamental Freedoms, Nov. 4, 1950, 213 U.N.T.S. 222; Regina v. Secretary of State for the Home Dep't (Brind), [1991] 1 App. Cas. 696 (U.K.) (upholding, against Convention-based challenge, broadcasting ban for certain Northern Ireland groups because Convention is not part of domestic law, though Convention is available as aid for interpreting ambiguous statutes). The last attempt to pass a fundamental rights charter in the United Kingdom Parliament was the Human Rights Bill, which failed to obtain a second reading in the House of Commons in 1987. See 109 PARL. DEB., H.C. (6th ser.) 1223-89 (1987); Peter Riddell, Human Rights Bill Support Fails, FIN. TAES, Feb. 7, 1987, at 1.

A recent Market and Opinion Research International poll shows growing public support for a bill of rights. In this poll, seven out of ten people supported the enactment of a bill of rights; seven out of ten also supported the use of referenda to decide important issues. Robin Oakley, Plea for More Referendums as One in Two Endorses PR, THE TIMEs (London), Apr. 25, 1991, at 4; Ivor Owen, Half of Electorate Found to Support System of $P R$, FN. TMMES, Apr. 25, 1991, at 10.

2. E.C.S. Wade, Introduction to A.V. DICEY, INTRODUCTION TO THE STUDY OF THE LAW OF THE CONSTITUTION, at xvii, xxxiv (10th ed. 1959). 
provisions of a bill of rights.

This Note confronts the dilemma of a bill of rights that strives to restrict the power of the state in a land where Parliament is by tradition sovereign, and thereby omnipotent. The Note examines the possibility of entrenching a bill of rights, thereby immunizing its provisions against ordinary Westminster legislation. By an "entrenched" clause, the Note means "[a] clause in a constitution or statute which can be amended or repealed only by special procedure or by a stated majority and is thereby to some extent protected from hasty or casual amendment." 3 This Note concludes that entrenchment can and should be sought by means of a parliamentary act predicated upon a popular mandate expressed in a referendum of the People.

In considering the issue, this Note will not question whether the enactment of a bill of rights would be prudent; the Note will assume that it would. ${ }^{4}$ Instead, the Note will concern itself with the possibility that once a bill of rights is passed, it might subsequently fall victim to parliamentary attack.

Part I of the Note explores the question of whether a bill of rights passed as an entrenched constitutional instrument is preferable to one passed as an ordinary statute. The Canadian experience with both a statutory and a constitu'ional bill of rights offers an important case study for this analysis. The examination of the Canadian case law will lead to the conclusion that, in order to be truly robust, a bill of rights should be entrenched as part of a "rigid" constitution, which cannot be amended by ordinary legislation. ${ }^{5}$

Part II turns to the question of how a bill of rights might be entrenched in the United Kingdom. ${ }^{6}$ Here, the Note will canvass the possible entrenchment

3. David M. Walker, THE OXFord Companion to LAW 421 (1980). Canadian Prime Minister Trudeau noted in the debate that culminated in the Canadian Charter of Rights and Freedoms, CAN. CONST. (Constitution Act, 1982) pt. I: "This is the essential meaning of entrenchment-that a constitutional charter by its overriding effect and its relative stability will preserve fundamental principles, providing a check on the exercise of power by governments of the day." Pierre E. Trudeau, The Constitution and the People of Canada: An Approach to the Objectives of Confederation, the Rights of People and the Institutions of Government (1968), reprinted in 1 CANADA's CONSTITUTION ACT 1982 AND AMENDMENTS: A DOCUMENTARY HistoRY 78, 82 (Anne F. Bayefsky ed., 1989). Trudeau went on to note, however, that a charter of human rights should not "stop at restricting governmental action . . . . [T] The charter should be self-denying for both governments and people, a shield against public or private interference with the rights of the individual." Id. While this Note is concerned primarily with parliamentary excess, a modern bill of rights may well need to protect against incursions from private as well as public sources. See Charles L. Black, Ir., The Supreme Court, 1966 Term-Foreword: "State Action," Equal Protection, and California's Proposition 14, 81 HARV. L. REV. 69, 109 (1967) (concluding that requirement of "state action" for judicial enforcement of Equal Protection Clause is a "threat to racial minorities"); Owen M. Fiss, Free Speech and Social Structure, 71 IowA L. REV. 1405 (1986) (arguing that media corporations, like the state, can restrict speech).

4. See, e.g., LESLIE SCARMAN, ENGLISH LAW-THE NEW DIMENSION (1974); RONALD DwoRKIN, A BILL OF RIGHTS FOR BRTTAIN (1990); William J. Brennan, Jr., Why Have a Bill of Rights?, 9 OXFORD J. LEGAL STUD. 425,440 (1989) ("I know of no surer weapon in that fight against our own fear and intolerance than an entrenched, enforceable bill of rights.").

5. A.V. DICEY, INTRODUCTION TO THE STUDY OF THE LAW OF THE CONSTITUTION 91 (10th ed. 1959). The U.K. constitution is currently a flexible one. But see infra note 31 and accompanying text.

6. "The constitution of the UK is largely unwritten. It consists partly of statutes, for the amendment of which by subsequent statutes no special procedure is required, but also, to a very significant extent, of 
methods and will ultimately reject the mechanism most commonly advanced. The modern analysis of the entrenchment question generally asks what types of restrictions one Parliament can legitimately impose upon future Parliaments. Some modern scholars have argued that while Parliament cannot restrict the substance of furure legislation, it can place "manner and form" or procedural restrictions on the enactment of future legislation on a particular matter. This Note, however, finds the case law inconclusive as to the ability of Parliament to entrench through manner and form restrictions. While the judiciary is willing to enforce higher law against legislative acts, it is unclear whether it would be willing to enforce prior acts of Parliament against subsequent Parliaments.

This Note finds limits on the entrenchment powers of Parliament in the principle of the political sovereignty of the People, a principle of the U.K. constitution expounded by A.V. Dicey, a figure who is sometimes regarded as "Britain's substitute for a codified constitution."7 Entrenchment procedures should not detract from the power of future mobilized majorities to govern themselves. This restriction applies not only to any particular Parliament, but to any particular generation of People as well.

Part III argues that the success of an attempt to entrench a norm depends less on whether an entrenchment is absolute or procedural than on how the norm is established. Most writers on the subject assume that only Westminster can generate legal norms. This Note disagrees and proposes enacting a bill of rights through some direct expression of popular assent, rather than through an ordinary statute. ${ }^{8}$ Such popular assent is crucial for the judicial enforcement of the charter of rights. ${ }^{9}$

Finally, Part IV argues that the major referenda of the 1970's provide support for the proposition that referenda on certain types of constitutional issues may well be required as part of an emerging convention of the U.K. constitution. $^{10}$

common law rules and constitutional conventions." A CONCISE DICTIONARY OF LAW 89 (2d ed. 1990) [hereinafter DICTIONARY] (citation omitted).

7. Vernon Bogdanor, Constitutional Law and Politics, 7 OXFORD J. LEGAL STUD. 454, 455 (1987).

8. Because of the ready availability of precedents for referenda, see infra Part $\mathrm{IV}$, this Note will assume that popular assent, or lack thereof, will be manifested in a referendum. Other mechanisms for ascertaining the "will" of the People-for example, a constitutional assembly-are available and may arguably be preferable on the grounds that they may elicit a more considered or high-minded vote. Some have also disputed the ability of referenda to reflect accurately the opinion of the People. See, e.g., Julian N. Eule, Judicial Review of Direct Democracy, 99 YALE L.J. 1503, 1513-22 (1990). But see, e.g., A.V. Dicey, The Referendum, NAT'L REV., Mar. 1894, at 65, 71-72 (advocating referendum mechanism because it allows electors to vote on single issue, rather than on issues bundled together in vote for member of Parliament).

9. Vernon Bogdanor describes the referendum as "a weapon of entrenchment." VERNON BOGDANOR, THE PEOPLE AND THE PARTY SYSTEM: THE REFERENDUM AND ELECTORAL REFORM IN BRITISH POLITICS 69-72 (1981).

10. Constitutional conventions are "lpIractices relating to the exercise of their functions by the Crown, the government, Parliament, and the judiciary that are not legally enforceable but are commonly followed as if they were." DICTIONARY, supra note 6, at 89. See generally Madzimbamuto v. Lardner-Burke, [1969] 1 App. Cas. 645, 723 (P.C. 1968) (appeal taken from Southern Rhodesia) (Lord Reid) (noting that convention restricting U.K. Parliament from legislating for Southern Rhodesia without Rhodesian approval was "very important convention but it had no legal effect in limiting the legal power of Parliament"). 


\section{AN ENTRENCHED OR A STATUTORY BILl OF RIGHTS? THE CANADIAN EXPERIENCE}

In 1960, the Canadian Parliament passed the Canadian Bill of Rights ${ }^{11}$ as an ordinary statute. The Bill of Rights requires courts to construe all federal legislation to conform to its requirements unless the legislation explicitly provides otherwise..$^{12}$ In the 1970 case of Regina v. Drybones,,$^{13}$ the Supreme Court of Canada read this construction power broadly, observing that "if a law . . . cannot be 'sensibly construed and applied' so that it does not abrogate ... the Bill, then such law is inoperative" unless the law expressly declares otherwise. ${ }^{14}$ The court threw out a provision of the Indian Act which made it illegal for Indians (but not others) to be intoxicated in certain circumstances. While Drybones suggested that the rights recognized in the Bill of Rights would be vindicated against parliamentary acts, the court, in cases after Drybones, "failed to live up to its promise." 15 For example, in Attorney General v. Lavell, ${ }^{16}$ the court upheld a section of the Indian Act that discriminated on the basis of sex, even though such discrimination was contrary to the Canadian Bill of Rights. The court found the Bill of Rights ineffective against legislation passed pursuant to a constitutional power ${ }^{17}$ to regulate the lives of Indians on reservations. The reasoning utilized in Lavell resulted in very limited protection of rights against legislative action: "In the two decades since the Bill's passage the Drybones case is still the only one in which a statute has been held to be inoperative for breach of the Bill."18

At the same time the court hesitated to apply the Bill of Rights against plainly inconsistent statutes, it also failed to read the rights expansively. In the 1963 case, Robertson \& Rosetanni v. Regina ${ }^{19}$ the court held that the Lord's Day Act, a Sunday observance law, did not violate the Canadian Bill of Rights' freedom of religion guarantee. The court maintained that the Bill of Rights protected only those rights that "existed in Canada immediately before the

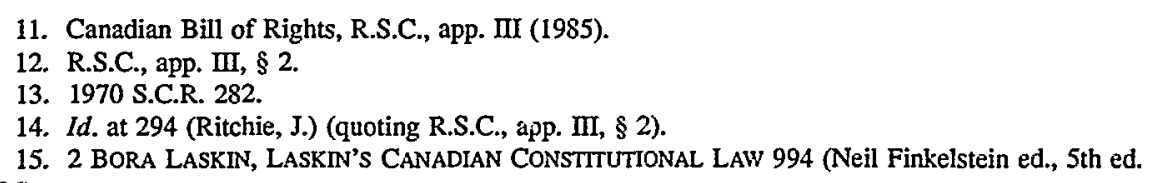
1986).

16. 1974 S.C.R. 1349 (1973).

17. The constitutional authority for this power is the British North America Act of 1867. CAN. CONST. (Constitution Act, 1867). The British North America Act of 1867 united three colonies of British North America into one dominion and set forth, inter alia, the legislative powers of the federal and provincial legislatures. CAN. CONST. (Constitution Act, 1867) $\S \S 3,91-92$.

18. Peter W. Hogg, A Comparison of the Canadian Charter of Rights and Freedoms with the Canadian Bill of Rights in THE CANADIAN CHARTER OF RIGHTS AND FREEDOMS: COMMENTARY 1, 21 (Walter S. Tarnopolsky \& Gerald-A. Beaudoin eds., 1982); see also Berend Hovius, The Legacy of the Supreme Court of Canada's Approach to the Canadian Bill of Rights: Prospects for the Charter, 28 MCGILL L.J. 31,39 (1982).

19. 1963 S.C.R. 651. 
statute was enacted" in $1960 .{ }^{20}$ Neither the wording nor the status of the Canadian Bill of Rights necessitated judicial restraint; ${ }^{21}$ however, the Bill's language and nonconstitutional status made it much easier for an already hesitant judiciary to read the rights narrowly. ${ }^{22}$

On the other hand, the jurisprudence under the Charter of Rights and Freedoms ${ }^{23}$ has been dramatically different, with judges freely invoking the constitutionally entrenched nature of the Charter to support broad readings of the rights granted therein. An act of the U.K. Parliament ${ }^{24}$ entrenched the Charter in 1982. Up till then, the U.K. Parliament had reserved to itself the exclusive right to amend Canada's basic constitutional document, the British North America Act of $1867 . .^{25}$ With this entrenchment, it is clear beyond cavil that the Charter is higher law, effective against both prior and subsequent acts of the federal and provincial legislatures. ${ }^{26}$ For example, in Regina $v$. Big M Drug Mart Ltd. ${ }^{27}$ the court invalidated the Lord's Day Act, which the court had earlier upheld under the Canadian Bill of Rights in Robertson \& Rosetanni. Justice Wilson declared: "[T] he constitutional entrenchment of civil liberties in the Canadian Charter of Rights and Freedoms necessarily changes the analytic approach the courts must adopt in such cases."28 The court suggested that the "interpretation should be ... a generous rather than a legalistic one, aimed at fulfilling the purpose of the guarantee and securing for individuals the full benefit of the Charter's protection." 29 Thus, the entrenchment of civil liberties in Canada through the Charter of Rights and Liberties has had two main

20. Id. at 654 (Ritchie, J.). The idea expressed in this passage became known as the "frozen concepts" principle. See Hovius, supra note 18 , at $40-42$.

21. Hovius, supra note 18, at 52-53.

22. Consider Justice Le Dain's dissent in Regina v. Therens: "[T] he courts have felt some uncertainty or ambivalence in the application of the Canadian Bill of Rights because it did not reflect a clear constitutional mandate to make judicial decisions having the effect of limiting or qualifying the traditional sovereignty of Parliament." [1985] I S.C.R. 613, 639 (Le Dain, J., dissenting), cited with approval in Reference re Section 94(2) of the Motor Vehicle Act, [1985] 2 S.C.R. 486, 499, 510 (Lamer, J.).

23. CAN. CONST. (Constitution Act, 1982) pt. I.

24. The Canada Act, 1982, ch. 11 (U.K.). The Act was passed upon the request of the Canadian Parliament. PETER W. Hogg, Constrtutional LAW OF CANADA 45 (2d ed. 1985).

25. Reference re. Amendments of the Constitution of Canada (Nos. 1, 2, and 3), [1981] 1 S.C.R. 753, 802 (noting "the need to resort to the British Parliament to amend the British North America Act, 1867").

26. The Constitution Act, 1982 declares: "The Constitution of Canada is the supreme law of Canada, and any law that is inconsistent with the provisions of the Constitution is, to the extent of the inconsistency, of no force or effect." CAN. CONST. (Constitution Act, 1982) pt. VII, $\S 52(1)$. Furthermore, section 24(1) of the Charter provides that courts can provide "appropriate and just" remedies for infringement of rights granted in the Charter. CAN. Const. (Constitution Act, 1982) pt. I (Canadian Charter of Rights and Freedoms), \& 24(1). The Charter allows the federal parliament and the provincial legisiatures to derogate from certain provisions of the Charter for five-year periods upon the passage of an act explicitly declaring this derogation. CAN. CONST. (Constitution Act, 1982) pt. I (Canadian Charter of Rights and Freedoms), §33.

27. [1985] I S.C.R. 295.

28. Id. at 359 (Wilson, J.).

29. Id. at 344 (Dickson, J.) (emphasis added); see also Reference re Section 94(2) of the Motor Vehicle Act, [1985] 2 S.C.R. at 495-500 (Lamer, J.); Hunter v. Southam Inc., [1984] 2 S.C.R. 145, 155 (Dickson, J.) ("The task of expounding a constitution is crucially different from that of construing a statute."); Law Soc'y of Upper Can. v. Skapinker, [1984] 1 S.C.R. 357, 365-68 (Estey, J.). 
effects: (1) the judiciary has nullified acts of Parliament that violated rights secured by the Charter; and (2) the judiciary has read those rights more expansively, giving them broad protection against the state.

While the entrenchment of a bill of rights does not guarantee that the courts will interpret civil liberties in this way, entrenchment does tend to elicit such a reading. In order to receive a similar level of protection from the judiciary, a U.K. bill of rights should unambiguously declare its own supremacy over inconsistent prior and subsequent acts of Parliament. It should explicitly empower courts to provide appropriate remedies, including the power to declare legislation invalid. And it should include a procedure for its own amendment.

\section{ENTRENCHMENT MECHANISMS}

\section{A. An Entrenchment Taxonomy}

The exact meaning of entrenchment depends on which of two forms it takes. Absolute entrenchment renders the entrenched rule permanent and immutable, inaccessible even to extraordinary constitutional processes. The German Constitution, which declares that certain fundamental principles are immune to constitutional amendment, provides an example of this form of entrenchment. ${ }^{30}$ Even the U.K. constitution might include some absolutely entrenched clauses. ${ }^{31}$ An absolutely entrenched clause is, however, (as are all other parts of an existing legal regime) vulnerable to revolution.

With procedural entrenchment, the entrenched provision is not subject to amendment or repeal through the normal legislative process, but instead only through an extraordinary process. "Manner and form" restrictions are placed on the enactment of future legislation that tries to change the entrenched provision. In other words, the manner in which future contrary legislation is enacted, or the form in which this legislation is drafted, must follow certain

30. GRUNDGESETZ [Constitution] [GG] art. 79(3) (making void any attempt to change certain principles regarding nature of German state, including principle that power inheres in the People). Even this provision may not be absolutely entrenched, as the Basic Law allows for a procedure which might be subverted to amend the supposedly unalterable principles. See id. art. 146 (allowing for adoption of new constitution). But cf. 1 BRUCE ACKERMAN, WE THE PEOPLE: FOUNDATIONS $326 \mathrm{n} .20$ (1991) (suggesting that using article 146 to amend the unalterable principles would be "great abuse" of article).

31. An Act for An Union of the Two Kingdoms of England and Scotland, 5 Anne, ch. 8 (1707) (Eng.), one of the constitutive events for Westminster Parliament, may absolutely entrench certain provisions. See $i d$. art. XIX \& pts. II-IX; see also STANLEY DE SMITH \& RODNEY BRAZIER, CONSTITUTIONAL AND ADMINISTRATIVE LAW 73-74 (6th ed. 1989) (noting that established church in Scotland and Scottish system of judicature may be "entrenched as fundamental and unalterable"). But see MacCormick v. Lord Advocate, 1953 Sess. Cas. 396, 411-13 (Scot. Sess.) (Lord Cooper) (noting that, while Treaty of Union-called "Act of Union" in English courts-may create "fundamental law," challenge to act of Parliament for violating Treaty not justiciable); H.W.R. WADE, CONSTITUTIONAL FUNDAMENTALS 33 (1980) (concluding that, though reasonable argument exists for Church of Scotland being established as fundamental by Act of Union, this argument is "not acceptable to courts" because of historical reasons). 
special methods for overriding the entrenched provision. ${ }^{32}$

One common type of manner and form entrenchment requires that all contrary legislation contain an explicit declaration of its intent to override the entrenched rule..$^{33}$ It logically follows that courts considering recent contrary legislation that lacks such a declaration will either construe the legislation to accord with the earlier provisions or declare the newer legislation invalid.

Other variants of procedural entrenchment include the supermajority requirement, by which some special majority of the legislature is required to override an entrenched provision. Procedural entrenchment might also be attained by requiring multiple votes of the legislature for an overriding provision to become or remain effective. Alternatively, entrenchment might also require that the People approve any changes, perhaps through a referendum, a constitutional assembly, or a caucus. ${ }^{34}$

\section{B. Entrenchment Possibilities in United Kingdom Law}

\section{Orthodox and New Views of Parliamentary Sovereignty}

The traditional theory of parliamentary sovereignty, as pronounced by Dicey, insists that "a sovereign power cannot, whilst retaining its sovereign character, restrict its own powers by any particular enactment." 35 Thus, Parliament, as the legal sovereign, cannot bind its successors, either with absolute or procedural restrictions. Legislation passed by a simple majority of each House and assented to by the Crown is always valid, regardless of earlier attempts to change the manner and form of lawmaking.

A rapidly emerging "new view" of parliamentary sovereignty insists that Parliament possesses a limited power to impose restrictions on future Parliaments. By changing the manner and form required for future legislation in a particular area, "a sovereign legislature may validly reformulate what shall count as legislation for particular purposes."36 As H.L.A. Hart writes: "[I]n

32. The classification of entrenchment types offered here differs significantly from some other expositions on the nature of entrenchment. See, e.g., JOSEPH JACONELLI, ENACTING A BILL. OF RIGHTS 15962 (1980) (suggesting tripartite division into subject matter, manner and form, and "inoperative"-rendering forms of entrenchment). The difference in classification is important because this Note contends that the procedural entrenchment category is much broader than often realized. Recognizing the actual scope of procedural entrenchment is essential to realizing the true extent of the parliamentary power that the "new view" of parliamentary sovereignty implicates. See infra Part II.B.1. $\S 33$.

33. See, e.g., CAN. CoNst. (Constitution Act, 1982) pt. I (Canadian Charter of Rights and Freedoms),

34. Certain procedural restrictions may well be so onerous as to be tantamount to absolute entrenchment of that norm. See T.R.S. Allan, Parliamentary Sovereignty: Lord Denning's Dexterous Revolution, 3 OXFORD J. LEGAL STUD. 22, $31 \mathrm{n} .33$ (1983). If a constitutional structure allows for procedural, but not absolute, entrenchment, courts might well be required to look behind proposed amendment procedures to see if they can be fulfilled in practice.

35. DICEY, supra note 5 , at 68 n.1.

36. GEOFFREY MARSHALL, CONSTITUTIONAL THEORY 43 (1971). 
relation to these special issues, Parliament has not 'bound' or 'fettered' Parliament or diminished its continuing omnipotence, but has 'redefined' Parliament and what must be done to legislate." 37 A bill of rights might be entrenched under the "new view" simply by Parliament's passing an act to redefine itself. Such a reconstituted Parliament might, for example, include a third House-consisting of the People-whose assent would be necessary to legislate contrary to the entrenched bill of rights.

Some scholars find support for this "new view" of parliamentary sovereignty in the case law and in parliamentary history. ${ }^{38}$ They cite for support Attorney General for New South Wales $v$. Trethowan, ${ }^{39}$ in which the Privy Coun$\mathrm{cil}^{40}$ enforced a manner and form restriction against the state legislature of New South Wales, Australia. The case involved the Colonial Laws Validity Act of 1865 , which had authorized colonial legislatures to determine their own powers and procedures. The New South Wales legislature exercised this power in 1929 to amend its constitution so that its upper house could be abolished only with the approval of the electorate in a referendum. In 1931 when the opposition came into power, it abolished the upper house without holding the required referendum. The Privy Council found the proposed abolition illegal because it did not follow the procedure set forth in the 1929 Act. Since a U.K. court was willing to enforce a manner and form entrenchment in Trethowan, some "new view" adherents take the case as precedent for Westminster's ability to bind itself in a similar manner. ${ }^{41}$

Two other cases before the Privy Council suggest that courts may hold manner and form restrictions binding on future legislatures. In the 1964 case of Bribery Commissioner v. Ranasinghe, the Privy Council considered the Ceylon Constitution's requirement that all amendments be endorsed by a Speaker's certificate stating that they had received a two-thirds majority in the House of Representatives. ${ }^{42}$ The court found the Bribery Amendment Act of 1958 unconstitutional because it did not carry the requisite certificate. In Attorney-General of Trinidad and Tobago v. McLeod, the respondent claimed that an act to amend certain entrenched sections of the Constitution of Trinidad and Tobago was void because it did not follow the procedure for amendment outlined in the entrenching clauses of the Constitution. ${ }^{43}$ The Privy Council

37. H.L.A. HART, THE CONCEPT OF LAW 147 (1961). In the paragraph that follows this quotation, Hart admits that the distinction between a "bound" and a "redefined" Parliament is, in fact, difficult to maintain. Id.

38. See DE SMITH \& BRAZIER, supra note 31, at 88-92; JACONELLI, supra note 32 , at 166-68.

39. 1932 App. Cas. 526 (P.C. 1931) (appeal taken from Austl.).

40. The Judicial Committee of the Privy Council hears cases from certain former colonies assenting to its jurisdiction. It also hears certain domestic cases from ecclesiastical courts and from the Prize Court. Formally, it is not a court at all, as its judgments are only advice to the Queen. See DE SMTTH \& BRAZIER, supra note 31 , at $152-58$.

41. See sources cited supra note 38.

42. 1965 App. Cas. 172 (P.C. 1964) (appeal taken from Ceylon).

43. [1984] 1 W.L.R. 522 (P.C.) (appeal taken from Trin. \& Tobago). 
found that the act had been enacted in the proper manner and form (namely, a two-thirds majority of each House), and that it was therefore a valid constitutional amendment.

These cases demonstrate the Privy Council's willingness to enforce manner and form restrictions on colonial legislatures. There are several other Commonwealth cases in which the Privy Council exercised a general power of judicial review (at least over acts of foreign Commonwealth legislatures) to determine the constitutionality of an act. ${ }^{44}$ Although in these cases the Privy Council usually held the impugned statute constitutional, it found the inquiries into the constitutionality of legislation valid, and it assumed the power to engage in such review.

However, the jurisprudence of the Privy Council in relation to foreign Commonwealth legislatures is not, as the "new view" school claims, readily transferable to the domestic U.K. context. The colonial legislatures have "rigid" constitutions, generally promulgated by the Westminster Parliament, which require obedience. The constitution of the U.K. is, on the other hand, a "flexible" one, susceptible to revision by ordinary acts of Parliament. As the Privy Council noted in Ranasinghe: "[I]n the Constitution of the United Kingdom there is no governing instrument which prescribes the law-making powers and the forms which are essential to those powers." 45 The fact that colonial Commonwealth legislatures were bound by the manner and form restrictions put forth under the authority of the Imperial Parliament does not necessarily imply that the U.K. Parliament can limit itself in a similar way. ${ }^{46}$

Furthermore, U.K. courts are reluctant to engage in any sort of judicial review of Westminster legislation, comforting themselves instead with a superficial glance at the parliamentary roll to see if a law has been validly enacted. ${ }^{47}$ In British Railways Board v. Pickin, ${ }^{48}$ for example, the House of Lords refused

44. See Haw Tua Tau v. Public Prosecutor, 1982 App. Cas. 136 (P.C. 1981) (appeal taken from Sing.) (upholding, as constitutional, amendments to Singapore Criminal Procedure Code allowing for adverse inferences from defendant's refusal to testify); Ong Ah Chuan v. Public Prosecutor, 1981 App. Cas. 648 (P.C. 1980) (appeal taken from Sing.) (holding that Singapore drug legislation accords with Constitution of Singapore, which includes common law rules of fundamental justice); Hinds v. The Queen, 1977 App. Cas. 195 (P.C. 1975) (appeal taken from Jam.) (finding unconstitutional several provisions of 1974 Jamaican act establishing special court and special criminal procedure for firearms offenses); Rediffusion (Hong Kong) Ltd. v. Attorney Gen. of H.K., 1970 App. Cas. 1136 (P.C.) (appeal taken from H.K.) (holding that court had jurisdiction to inquire into legislative deliberative process, but not finding cause of action against Hong Kong legislators who passed law violating Imperial Parliament law); Liyanage v. The Queen, [1967] 1 App. Cas. 259 (P.C. 1965) (appeal taken from Ceylon) (holding invalid, under separation of powers implicit in Ceylon Constitution, Ceylon legislation ad hominem and ex post facto, passed in response to abortive coup d'etat); Chenard \& Co. v. Arissol, 1949 App. Cas. 127 (P.C. 1948) (appeal taken from Sey.) (holding that Seychelles Penal Code's grant of immunity was within powers established by Imperial Parliament for Seychelles Legislative Council).

45. 1965 App. Cas. at 195.

46. See O. Hood Phillips, Self-Limitation by the United Kingdom Parliament, 2 HASTINGS CONST. L.Q. 443, 455 (1975); H.W.R. Wade, The Basis of Legal Sovereignty, 1955 CAMBRIDGE L.J. 172, 182.

47. See Edinburgh \& Dalkeith R.R. v. Wauchope, 8 Eng. Rep. 279, 285 (H.L. 1842) (Lord Campbell)

("All that a Court of Justice can do is to look to the Parliamentary roll . . . .").

48. 1974 App. Cas. 765. 
to look behind the procedure used to enact a statute to see if British Railways had fraudulently concealed information from Parliament. Lord Reid stated that "[t]he function of the court is to construe and apply the enactments of Parliament." 49 Thus, the willingness of the Privy Council to review the actions of foreign legislatures does not necessarily translate into a willingness of U.K. courts to review acts of the Westminster Parliament.

Supporters of the "new view" also find support ${ }^{50}$ in the Parliament Acts of $1911^{51}$ and $1949^{52}$ for the proposition that the Westminster Parliament has the same power to redefine how legislation is enacted (i.e., to engage in manner and form entrenchment) that colonial parliaments possess. In response to the defeat of the Liberal government's social welfare legislation by the Conservative-dominated House of Lords, the Liberals enacted the Parliament Act of 1911 to restrict the Lords' ability to veto legislation. This Act passed through the House of Lords with the help of King George V's threat to pack the peerage in order to overwhelm the opposition in the Lords. ${ }^{53}$ With the Act's passage, the Lords could delay money bills for a maximum of only one month, and other bills (with a few exceptions) for only two years. ${ }^{54}$ The Parliament Act of 1949 further restricted the maximum delay of any public bill to one year. ${ }^{55} \mathrm{Few}$ have questioned these parliamentary actions which redefined how future Parliaments legislate. ${ }^{56}$ Indeed, the House of Commons has, under the authority of the Parliament Act of 1911, passed three acts without the Lords' assent. ${ }^{57}$

There is, however, a difficulty in using this example as precedent for a parliamentary power of entrenchment through manner and form restrictions on future Parliaments. The procedural restrictions that the Parliament Acts imposed on future Parliaments did not in fact entrench any specific act of Parliament. While the Parliament Act of 1911 was used to help pass the Liberal government's budget, the Act was not intended to immunize the budget against attacks from future Parliaments. The Parliament Acts, in fact, made it easier to pass laws. Manner and form restrictions that entrench involve different normative considerations than manner and form restrictions that simply change the way future law is made. Entrenching restrictions differ from non-entrenching restrictions in that the former are intended to create a bias in favor of the post-entrenchment status quo on a particular subject matter. Because of this subject

\footnotetext{
49. $I d$. at 787 (Lord Reid).

50. See, e.g., DE SMITH \& BRAZIER, supra note 31 , at 88-91.

51. The Parliament Act, $1911,1 \& 2$ Geo. 5 , ch. 13 (U.K.).

52. The Parliament Act, 1949, 12, 13 \& 14 Geo. 6, ch. 103 (U.K.).

53. See DE SMITH \& BRAZIER, supra note 31 , at 304.

54. The Parliament Act, 1911, 1 \& 2 Geo. 5, ch. 13, §s 1 \& 2 (U.K.).

55. The Parliament Act, 1949, 12, 13 \& 14 Geo. 6, ch. 103, § 1 (U.K.).

56. See, e.g., O. HOOD PHILLIPS \& PAUL JACKSON, CONSTITUTIONAL AND ADMINISTRATIVE LAW 90-91, 149 (7th ed. 1987).

57. These are the Welsh Church Act of 1914, 4 \& 5 Geo. 5, ch. 91 (U.K.); the Government of Ireland Act of 1914, 4 \& 5 Geo. 5, ch. 90 (U.K.); and the Parliament Act of 1949, 12, 13, \& 14 Geo. 6, ch. 103 (U.K.); see also DE SMITH \& BRAZIER, supra note 31, at 305.
} 
bias, entrenching restrictions can pose serious "dead hand of the past" problems: future generations must live with the substantive law of earlier times unless they can find the special resolve needed to overcome the procedural restriction. Therefore, the fact that the U.K. constitution allows for non-entrenching manner and form restrictions (as evidenced by the Parliament Acts of 1911 and 1949) does not mean that the constitution must also allow for entrenching procedural restrictions. Courts may be willing to accept nonentrenching manner and form restrictions, but not entrenching ones.

\section{Impact of European Community Accession on Sovereignty}

The U.K.'s accession to the European Community (EC) has dramatically affected the nature of U.K. law. ${ }^{58}$ The European Communities Accession Act of 1972 sets out the following principles for dealing with Community law in the U.K.: (1) EC law shall be given legal effect in the U.K. without need for incorporation through an act of Parliament; (2) any act of Parliament passed before or after enactment of the European Communities Accession Act of 1972 shall be construed according to EC law; and (3) domestic courts shall decide questions of EC law according to principles laid down by the European Court of Justice. ${ }^{59}$ The decisions of the European Court establish that, as a matter of Community law itself, Community law is superior to the national laws of member states. ${ }^{60}$

The domestic view of the relationship between Community and national law is more complex. In Macarthys Ltd. $v$. Smith ${ }^{61}$ the Court of Appeals found that the Community law standard for determining sex discrimination in wages took priority over the domestic law standard. Lord Denning wrote: "Community law is now part of our law: and, whenever there is any inconsistency, Community law has priority." ${ }^{2}$ However, the House of Lords in Garland v. British Rail Engineering $L t .^{63}$ implied that "an express positive statement in an Act" of an intention to breach a Community law obligation would be enforced in the courts. ${ }^{64}$ These two cases taken together support the conclusion that the European Communities Act "entrenches Community law against

58. See generally THE EFFECT ON ENGLISH DOMESTIC LAW OF MEMBERSHIP OF THE EUROPEAN COMMUNITIES AND OF RATIFICATION OF THE EUROPEAN CONVENTION ON HUMAN RIGHTS (M.P. FurmSton et al. eds., 1983) [hereinafter MEMBERSHIP]; J.D.B. Mitchell, What Happened to the Constitution on 1st January 1973?, 11 CAMBRIAN L. REV. 69 (1980).

59. European Communities Act, 1972, ch. 68, §§ 2(1) \& (4), 3(1) (U.K.).

60. See Case 106/77, Amministrazione delle Finanze dello Stato v. Simmenthal S.p.A., 1978 E.C.R. 629, [1978] 3 C.M.L.R. 263 (Prelim. Ruling); Case 6/64, Costa v. ENEL, 1964 E.C.R. 585, [1964] 3 C.M.L.R. 425 (Prelim. Ruling); see also Case 213/89, Regina v. Secretary of State for Transp. (Factortame), [1990] 3 C.M.L.R. 1 (holding that domestic U.K. courts must be able to grant interim relief against domestic legislation that contravenes $\mathrm{EC}$ law).

61. [1981] 1 Q.B. 180 (C.A. 1980).

62. Id. at 200 (Lord Denning).

63. [1983] 2 App. Cas. 751 (1982).

64. Id. at 771 (Lord Diplock). 
implied repeal but not against any provision stating . . . that it is to have effect notwithstanding Community law."

In the 1990 proceedings in Regina v. Secretary of State for Transport (Factortame), ${ }^{66}$ the House of Lords accepted a European Court of Justice decision that national courts were duty bound to grant interim injunctions against national statutes that violated directly applicable Community law. Lord Bridge confronted the issue of parliamentary sovereignty. He argued that, since the "supremacy" of Community law was well established in the case law of the European Court of Justice when the U.K. joined the Community, "whatever limitation of its sovereignty Parliament accepted when it enacted the EC Act 1972 was entirely voluntary." of Community law in the case at issue, it still remains unclear what the Lords would do if confronted with a parliamentary act that explicitly declared its supremacy over Community law. Conservative constitutional scholars might find in such a case the possibility of salvaging the sovereignty of Parliament. ${ }^{68}$

While an explicit derogation requirement (that is, a requirement of explicit rather than implicit repeal) offers some protection for an entrenched norm, it is nonetheless a weak form of entrenchment. The European Convention on Human Rights, for example, allows for explicit derogation from most of its provisions. ${ }^{69}$ This loophole has been exploited several times by the U.K., often in reference to Northern Ireland. ${ }^{70} \mathrm{~A}$ bill of rights that can be amended only by the People should be more secure.

65. D.N. Clarke \& B.E. Sufrin, Constitutional Conundrums-The Impact of the United Kingdom's Membership of the Communities on Constitutional Theory, in MEMBERSHIP, supra note 58, at 62 .

66. [1991] 1 App. Cas. 603 (1990) (granting interim injunction restraining government from withholding registration to fishing vessels owned by foreigners).

67. Id. at 658-59.

68. The theory proposed in this Note would interpret European Community accession as being consistent with a "dualist" constitution. See infra note 119. The EC referendum was an example of higher politics, a constitutional moment in which the People changed the method of normal politics so as to include the organs of the Community in everyday lawmaking. The locus of actual sovereignty did not change; it still lies with the People of the U.K., who retain the right to leave the EC or to condition its actions as they wish.

69. Convention for the Protection of Human Rights and Fundamental Freedoms, Nov. 4, 1950, 213 U.N.T.S. 222, art. 15(1) (allowing derogation "in time of war or other public emergency" from convention obligations, except those regarding right to life and freedom from torture, slavery, and ex post facto laws).

70. See Christopher Schreuer, Derogation of Human Rights in Sittations of Public Emergency: The Experience of the European Convention on Human Rights, 9 YALE J. WORLD PUB. ORD. 113, 117-18 (1982). 


\section{Summary: The Need for a Lex Superior}

Lex posterior derogat priori. ${ }^{71}$ A later act overrules an earlier one. The traditional doctrines of implied and explicit repeal do not allow even procedural entrenchment. ${ }^{72}$ The suggestion of the "new view" school that Parliament can redefine itself and thereby entrench its actions finds only tenuous support in the Commonwealth cases heard by the Privy Council. The Parliament Acts of 1911 and 1949 also offer little support for the power of procedural entrenchment because they did not entrench any norm. It is clear from the Commonwealth cases, however, that U.K. courts will enforce a higher law if one is found to exist. Accession to the European Community has created a "quasihigher law," demonstrating the possibility of creating a hierarchy of laws in which Westminster legislation does not necessarily occupy the highest rank.

Lex superior derogat inferior. Higher law supersedes lower law. Entrenchment, if it is to be effective, involves the creation of higher law. The modern U.K. constitution does not recognize principles of natural law as legally binding, ${ }^{73}$ so higher law must come from more mundane sources. How are such sources to be found? The next section argues that whatever method is established must stem from the ultimate sovereignty of the People. Indeed, even if the courts are willing to recognize a parliamentary power to entrench laws procedurally, that power should not be exercised.

\section{Sovereignty, Democracy, and the Limits of Entrenchment}

This section moves from the analysis of the possibility of entrenchment in U.K. case law to an examination of entrenchment in terms of the U.K. constitutional structure. It looks at some of the links between entrenchment, sovereign-

71. See EDWARD COKE, THE FOURTH PART OF THE INSTITUTES OF THE LAWS OF ENGLAND 43 (photo. reprint 1979) (London, M. Flesher 1628) ("[I]t is a maxim in the law of the Parliament, quod leges posteriores priores contrarias abrogant.").

72. The traditional view is expressed in Ellen St. Estates, Ltd. v. Minister of Health, [1934] 1 K.B. 590, 597 (C.A.) (Maugham, L.J.) ("The Legislature cannot, according to our constitution, bind itself as to the form of subsequent legislation, and it is impossible for Parliament to enact that in a subsequent statute dealing with the same subject-matter there can be no implied repeal."); see also Vauxhall Estates, Ltd. v. Liverpool Corp., [1932] 1 K.B. 733, 743 (Avory, J.).

73. See British Rys. Bd. v. Pickin, 1974 App. Cas. 765,782 (Lord Reid) (“[B]y the Revolution of 1688 any [idea of a higher natural law had] become obsolete."). Pickin thus denies the continuing validity of the statement of Edward Coke in Dr. Bonham's Case, 6 Eng. Rep. 646, 652 (1610) ("[T]he common law will controul Acts of Parliament, and sometimes adjudge them to be utterly void: for when an Act of Parliament is against common right and reason, or repugnant, or impossible to be performed, the common law will controul it, and adjudge such Act to be void." (citation omitted)). Some have argued that Coke was not in fact appealing to natural law in this dictum. See, e.g., S.E. Thorne, Dr. Bonham's Case, 54 L.Q. REv. 543, 552 (1938) (concluding that Coke's dictum was directed to judge's power to invalidate a statute for "indirect repugnances, that is, contradictions not on the statute's face"). Coke's dictum in Dr. Bonham's Case is, at least ostensibly, inconsistent with his declaration that "the power and jurisdiction of the Parliament for making of laws in proceeding by Bill ... . is so transcendent and absolute, as it cannot be confined either for causes or persons within any bounds." COKE, supra note 71, at 36. On Coke's apparent inconsistency, see 5 WILLIAM HOLDSWORTH, A HISTORY OF ENGLISH LAW 475 (3d ed. 1945). 
ty, and democracy. It begins by taking seriously Dicey's notion of the political sovereignty of the People. The political sovereignty of the People restrains the types of entrenchments that are legitimate within the confines of the U.K. constitution. Thus, it removes the "dead hand of the past" danger lurking in entrenchment.

\section{Political and Legal Sovereigns}

Dicey makes a distinction between the political and legal sovereigns of Britain, writing:

Parliament is, from a merely legal point of view, the absolute sovereign of the British Empire, since every Act of Parliament is binding on every court throughout the British dominions, and no rule, whether of morality or of law, which contravenes an Act of Parliament, binds any court throughout the realm. But if Parliament be in the eye of the law a supreme legislature, the essence of representative government is, that the legislature should represent or give effect to the will of the political sovereign, i.e. of the electoral body, or of the nation. ${ }^{74}$

In this way Dicey deftly combines the doctrine of parliamentary sovereignty with the idea of modern democracy. ${ }^{75}$ While popular political sovereignty is not explicitly recognized in U.K. law, the principle does find expression in U.K. constitutional conventions "which, in one way or another, are intended to produce harmony between the legal and the political sovereign power." Popular political sovereignty is an essential value of the constitution, informing its structure and rules.

While political sovereignty might be interpreted as merely the technical requirement that the People elect the legislators (at least in the Commons), Dicey's exposition makes it clear that it means much more. For example, Dicey points to the convention that "[i]f there is a difference of opinion between the House of Lords and the House of Commons, the House of Lords ought, at some point, not definitely fixed, to give way . ..." ${ }^{77} \mathrm{He}$ observes that this convention, like others, enhances the political sovereignty of the People. ${ }^{78} \mathrm{~A}$ convention of deference by the Lords to the Commons serves popular political sovereignty by giving priority to the representative branch of the legislature. Popular political sovereignty involves not only the technical right to elect legislators,

74. DICEY, supra note 5 , at 429-30 (emphasis added) (footnote omitted); see also Dicey, supra note 8 , at 70 (noting that "the electors ... . are the true sovereign of the country").

75. The idea that popular political sovereignty is Dicey's bow towards democracy is verified in E.C.S. Wade's introduction to Dicey's text: "[I]t is the political supremacy rather than the legal doctrine lof parliamentary supremacyl which saves the democratic principle." Wade, supra note 2, at cxciv.

76. DICEY, supra note 5, at 438; see also infra Part IV.D.

77. DICEY, supra note 5 , at 421 .

78. Id. at 431 ("Our modern code of constitutional morality secures, though in a roundabout way, what is called abroad the 'sovereignty of the people.'"). 
but also the right to have the will of the People observed in the legislature. While this right may not presently be justiciable, it is nevertheless firmly embedded in the structure of the constitution. ${ }^{79}$

\section{Democracy-Sustaining v. Democracy-Negating Entrenchments}

Not all manner and form restrictions are equal. Some procedural restrictions are more acceptable than others. Consider, for example, an act of one Parliament that required unanimity in both houses before future Parliaments could engage in contrary actions. Such a restriction would be tantamount to an absolute entrenchment, because unanimity would be extremely difficult $\omega$ obtain. Absolute entrenchment is generally accepted as being beyond the scope of the restrictions that a Parliament can constitutionally enforce upon future Parliaments. But that would not be the only problem with such a restriction: it would also, on its face, be undemocratic. If the current Parliament (or even the current People) could place such nearly insurmountable restrictions on the abilities of future Parliaments, future electorates would be effectively disenfranchised, at least in regard to those entrenched issues. Democracy cannot be sustained if more and more subjects can continually be declared outside the operation of normal democratic processes. The above example would, then, be a democracy-negating entrenchment.

Consider, by contrast, a norm entrenched with a manner and form restriction that required future Parliaments to gain the consent of a simple majority of the People before the norm could be amended or repealed. Such a restriction would merely require that the democratic process be employed to ascertain whether the People do in fact support the contrary legislation. Such a restriction would be entirely consistent with democratic principles; it would be a democracy-sustaining entrenchment. ${ }^{80}$

We can now characterize various proposed entrenchment procedures for a bill of rights in terms of this classification. A procedure requiring legislation derogating from the bill of rights to be passed by a two-thirds majority of the Commons would be democracy negating. ${ }^{81}$ This view of democracy as requiring simple majority rule is consistent with Dicey's view of political sovereignty:

79. See id. at 437 ("II]n short, the validity of constitutional maxims is subordinate and subservient to the fundamental principle of popular sovereignty.").

80. Whether one accepts democracy-sustaining or democracy-negating entrenchments as legitimate depends upon one's theory of the type of omnipotence that the People possess. To use Hart's terminology we can characterize omnipotence, for our purposes, as either "continuing" or "self-embracing." See HART, supra note 37, at 146. This Note favors the continuing omnipotence of the People; thus, by definition, only democracy-sustaining entrenchments are acceptable.

81. While eschewing the task of offering a complete vision of what democracy entails, this Note will assume that democracy requires, at a minimum, simple majority rule. This rule has a somewhat magical property. See AMARTYA K. SEN, COLLECTIVE ChOICE AND SOCIAL WELFARE 71-73 (1970) (proving May's theorem that simple majority rule is only collective choice rule that simultaneously satisfies positive responsiveness, neutrality, and anonymity conditions). 
"[T]he true political sovereign of the State," he writes, "[is] the majority of the electors." ${ }^{2}$ If the political sovereign is the majority of the electors, then sovereignty is lost when this majority cannot change the law by itself.

A procedure requiring multiple affirmations, either by the Parliament or by the People, of the desire to derogate from the bill of rights might well be democracy sustaining. If this requirement contributes to the deliberation of the People or to making certain that their preferences are stable, it would further the democratic process. Requiring too many successive votes, on the other hand, might frustrate the attempts of the People to enact even their well-considered will; such a multiple vote procedure would be democracy negating.

\section{Temporal Limits}

In the United States, as Julian Eule cogently argues, Congress is denied an entrenchment power because of the temporal nature of the legislative mandate. ${ }^{83}$ The authority granted to legislators is limited in time as well as in scope. Since they cannot make laws outside of their authority, they cannot make laws for a future over which they have not been given authority.

The theory of agency that informs the structure of the U.S. Constitution cannot be easily transported across the Atlantic. According to Dicey, the U.K. constitution does not rest on the principle that the legislator is either the agent or the trustee of the People. Dicey writes: "[I]n a legal point of view Parliament is neither the agent of the electors nor in any sense a trustee for its constituents." ${ }^{84}$ Therefore, we cannot rest a theory of the incapacity of Parliament to entrench on the American theory of a limited legislative mandate. Instead, limits on the entrenchment power in the U.K. must come from Dicey's doctrine of popular political sovereignty. Furthermore, the restrictions on entrenchment must apply not only to the legislature as they do in Eule's theory, but also to the People themselves.

Political sovereignty inhering in future generations requires that future peoples be able to enact their will through the political process. If the current Parliament or the current electoral majority can entrench its directives so that they are immune from the contrary desires of future majorities of the People, popular political sovereignty is destroyed. This is, of course, exactly the type of entrenchment that was characterized earlier as democracy negating. Thus,

82. DICEY, supra note 5, at 429 (emphasis added).

83. See Julian N. Eule, Temporal Limits on the Legislative Mandate: Entrenchment and Retroactivity, 1987 AM. B. FOUND. RES. J. 381, 403-05.

84. DICEY, supra note 5, at 47-48 (citing for support Septenniel Act of 1715, 1 Geo. 1, stat. 2, ch. 38 (Eng.), in which Parliament in 1716, without directly consulting the People, extended its life, and lives of future Parliaments, from three years to seven; this action clearly inconsistent with conception of legislators as agents with temporal restraints on their authority). But see Carol Harlow, Power from the People? Representation and Constitutional Theory, in LAW, LEGITMACY, AND THE CONSTITUTION 62, 74 (Patrick McAuslan \& John F. McEldowney eds., 1985) (arguing that because Dicey supported device of constitutional referenda later in life he supported cloctrine of limited trust of legislators). 
democracy-negating entrenchments are beyond the constitutional powers of the Parliament because they destroy the continuing political sovereignty of the People.

On the other hand, democracy-sustaining entrenchment procedures, by definition, promote popular political sovereignty. ${ }^{85}$ They do not involve the present Parliament or the present generation in a usurpation of the power of future generations; they instead give full effect to the democratically expressed will of future peoples. There is no "dead hand of the past" to shape the lives of future generations against their wishes.

\section{Criticism of "Manner and Form" Power of Parliament}

The unrestricted power to engage in procedural entrenchment that is implied by the "new view" is an awesome one and, as such, is open to great abuse. While we may be momentarily happy with the result of a particular entrenchment imposed by Parliament, especially one entrenching fundamental rights and liberties, we should be frightened by the precedent it sets. Such a power would allow a socialist government about to be replaced to entrench the socialist state into the constitution; it would allow a conservative government about to lose an election to entrench capitalism. Such "midnight raids" on the constitution are a frightening possibility if the right to entrench is conceded to be an ordinary power of Parliament, as it would be if Parliament were allowed on its own to entrench a bill of rights.

Furthermore, a parliamentary procedural entrenchment power is logically flawed because it suffers from the paradox of self-amendment noted by the Danish jurist Alf Ross. ${ }^{86}$ Ross demonstrated that it is logically impossible for one amendment process to authorize the creation of another, contradictory amendment process. The "new view" would allow Parliament to entrench a bill of rights by passing an act stating that no future act (that was passed the same way as the original act was passed) could amend the bill of rights. Such an entrenchment would be illogical. ${ }^{87}$ This Note, in contrast, proposes an entrenchment process that is not afflicted with the logical difficulty noted by Ross. The entrenched bill of rights proposed here would be susceptible to amendment through the same procedure used to entrench it-namely, a referendum.

85. The referendum mechanism, by which a majority of the People always retains the power to transform the laws, is democracy sustaining. Cf. Dicey, supra note 8 , at 69 ("IT) Re Rerendum, or the People's Veto, is an institution which is in absolute harmony with the democratic principles or sentiment of the day.").

86. See Alf Ross, On Self-Reference and a Puzzle in Constitutional Law, 78 MIND 1 (1969).

87. While logical incoherence may arguably not be fatal to the validity of a process of legal change, it does render a process imperfect. $C f$. PETER SUBER, THE PARADOX OF SELF-AMENDMENT: A STUDY OF LOGIC, LAW, OMNIPOTENCE, AND CHANGE 49 (1990) (arguing against Ross' requirement for logical consistency in legal change on grounds that, quoting Oliver Wendell Holmes, "[t]he life of the law has not been logic; it has been experience"). 


\section{Summary: The Limits of Entrenchment}

Entrenchment must be limited so that it does not usurp the power of future generations. Entrenchments by the Parliament and by the People must be consistent with the continuing political sovereignty of the People. A bill of rights entrenched by Westminster alone, while taking away from Parliament the power to violate certain rights, would give the current Parliament the extraordinary power to exercise its will over future generations.

Part II has argued that the principle of a continuing democracy places certain limits on entrenchment. Part III explains that the need for judicial enforcement further restricts entrenchments: in order to gain judicial support, entrenchments should spring from the People themselves.

\section{THE JUdICIARY AND ENTRENCHMENT}

It is in the breasts of the judges that the problem lies and it is in their breasts that we must contrive the solution.

$$
\text { H.W.R. Wade }{ }^{88}
$$

In order to be successfully entrenched, a bill of rights must be protected in the courts. U.K. courts must be available to enforce the bill of rights against violations by the state, including violations by Parliament. Claims based on the bill of rights must be justiciable; there must be individuals with standing to bring the claims to court; causes of action must lie directly under the bill of rights; and finally, remedies for violations must be available.

U.K. courts generally have found actions of police, immigration officers, the Home Office, and other administrative units illegal because they violated rights granted by acts of Parliament. ${ }^{89}$ Therefore, enforcement of a bill of rights against administrative action seems unproblematic. However, enforcement

88. WADE, supra note 31 , at 40 . Wade suggests a rather novel approach to entrenchment: "All that need be done in order to entrench any sort of fundamental law is to secure its recognition in the judicial oath of office." Id. at 37. For Wade's suggestion to be effective, the new oath presumably would have to require the judiciary to void any subsequent change in the oath that sought to undo the judge's official commitment to protecting the bill of rights. The bill of rights, in other words, would have to be "doubly entrenched." See DE SMITH \& BRAZIER, supra note 31, at 89 n.108. This fact leaves Wade's procedure with the same flaws as the manner and form method of entrenchment. First, both methods allow the current Parliament, either by "redefining" the legislative process or by drafting a new judicial oath, to impose its will on the future. Such a result contradicts Dicey's notion of popular political sovereignty, since it leads to the aggrandizement of power by the current Parliament at the expense of future Parliaments and future generations. See supra Part II.C. Second, Wade's judicial oath method of entrenchment also suffers from the logical inconsistency noted by Alf Ross, since Parliament would be using one amendment process (changing the judicial oath) to change the amendment process itself (so that a certain part of the judicial oath could not be changed). As Ross has demonstrated, one amendment process cannot logically be used to legitimize a different and contradictory amendment process. See supra note 86 and accompanying text.

89. See generally DE SMITH \& BRAZIER, supra note 31, at 471-76 (describing habeas corpus remedy, which includes judicial review of court actions); id. at $546-600$ (describing judicial review of administrative actions). 
of a bill of rights against recent and contrary parliamentary acts confronts the doctrine of parliamentary sovereignty. Even here, courts have indicated at least a willingness to hear cases challenging Parliament's competence to enact legislation contrary to earlier acts. In Blackburn v. Attorney-General, ${ }^{90}$ the Court of Appeals found that if Parliament attempted to repeal an earlier act-in this case, the treaty relating to European Community accession-a challenge to Parliament's action would indeed be justiciable. Lord Denning wrote: "I do not envisage that Parliament would afterwards go back on [European Community accession] and try to withdraw from it. But if Parliament should do so, then I say we will consider that event when it happens. We will then say whether Parliament can lawfully do it or not." ${ }^{\text {"91 }}$ Similarly, a claim regarding the ability of the Parliament to "go back on" a bill of rights should be justiciable.

The judiciary may fail to enforce a bill of rights against subsequent acts of Parliament unless it feels that the bill of rights represents higher law. The extraordinary step of going to the People to validate the enactment of a charter of rights will generate the necessary discourse about, and commitment to, a bill of rights as higher law. As New Zealand's Judge Robin Cooke has explained, it is essential to give a bill of rights "practical sanctity" through community consensus. ${ }^{92}$ Popular assent to the adoption of an entrenched bill of rights may well act as a magnetic force on the judiciary, attracting judges to the idea that the rights charter is higher law.

\section{ReFERENDA AS EMerging Constitutional CONVEntion}

The last two decades have seen three major attempts at constitutional change in the U.K. that were submitted to the people for their approval in a referendum. In 1973, Westminster asked the people of Northern Ireland whether they wished to remain a part of the U.K. In 1975, the accession of the U.K. to the European Community was put before the People for their approval. Finally, in 1979, the people of Scotland and Wales voted on whether to devolve power from Westminster in favor of local assemblies. These recent referenda on constitutional issues demonstrate that at times Parliament finds it lacks the competence to legislate changes without direct popular approval. ${ }^{93}$ These important precedents in recent U.K. history suggest the emergence of the following constitutional convention: Higher lawmaking that restricts the power

90. [1971] 1 W.L.R. 1037 (C.A.).

91. Id. at 1040 (Lord Denning).

92. Philip A. Joseph \& Gordon R. Walker, $A$ Theory of Constitutional Change, 7 OXFORD J. LEGAL STUD. 155, 168-69 (1987).

93. In later writings, Dicey himself supported the use of referenda to validate permanent constitutional changes. See Dicey, supra note 8, at 69 (advocating introduction of referendum mechanism for affirming constitutional changes so as "to moderate, if not to cure, the evils of Parliamentarism"); see also BOGDANOR, supra note 9, at 11-16; Harlow, supra note 84, at 74. 
of Parliament is not legitimate unless it is directly submitted to the People for their approval. ${ }^{94}$

The referenda discussed here are both richer in their implications for sovereignty ${ }^{95}$ and more complex in their workings than this Note describes. While this Note offers a simplified account, it is designed to demonstrate the importance that Parliament gave in each case to obtaining a plebiscite before undertaking a major constitutional change.

\section{A. The Northern Ireland Border Poll of 1973}

After the prorogation of the Stormont Parliament (the regional assembly for Northern Ireland) in March 1972, Westminster turned to a poll of the people of Northern Ireland to determine whether they wished to remain part of the U.K. ${ }^{96}$ The results of the poll on March 8, 1973, were as follows: $98.9 \%$ of those voting supported remaining in the U.K., and $1.1 \%$ of the voters preferred joining with the Irish Republic. ${ }^{97}$

The overwhelming majority for the status quo was due in large part to the boycott of the poll organized by the Social Democratic and Labour Party and other parties supported by the Catholic community. Republicans and Nationalists, who found the political division of Ireland into the North and the South fundamentally illegitimate, could not accept a poll of Northern Ireland alone; they desired instead an Ireland-wide referendum.

While the Northern Ireland referendum suffered from serious flaws that made it an imperfect expression of popular sovereignty, it served as an important precedent for future referenda. Westminster had felt a need to allow the people of Northern Ireland to speak directly on an issue of paramount importance. Since the people's right to speak, and thereby to control government, had been reduced by the dissolution of the local assembly, an alternative forum for exerting popular control was found in a referendum. "The precedent set in Northern Ireland," one commentator wrote, "prepared the Commons for the EEC referendum." $" 98$

94. See BOGDANOR, supra note 9 , at 76.

95. For example, what does the fact that some referenda were limited to the populations of their respective regions say about whether one true "People" exists in the U.K.? Furthermore, does popular sovereignty require that the result of an election be based on the number of people eligible to vote or on those actually voting? See Akhil R. Amar, Philadelphia Revisited: Amending the Constitution Outside Article $V, 55$ U. CHI. L. REv. 1043, 1064 n.78 (1988) (noting that those not voting might be deemed to have given their proxies to those who are). Also, did these referenda constitute "constitutional moments" of mass deliberation and mobilization? See ACKERMAN, supra note 30, at 285-88.

96. Northern Ireland (Border Poll) Act, 1972, ch. 77 (U.K.).

97. 71 THE TWENTIETH CENTURY STATUTES 1414 preliminary note (1973).

98. STANLEY ALDERSON, YEA OR NAY? REFERENDA IN THE UNITED KINGDOM 38 (1975); see also JO GRIMOND \& BRIAN NEVE, THE REFERENDUM 18 (1975). 


\section{B. The European Community Accession Referendum of 1975}

The U.K. became a full member of the European Community on January 1, 1973, following Parliament's ratification of the European Communities Act of $1972 . .^{99}$ Even though the legal requirements for EC entry had been met, strong opposition to membership remained.

In the general election of 1970 , this opposition had been unable to express its opinion at the ballot box. While it was the Conservatives, under Edward Heath, who had negotiated entry into the European Community, the two other major political parties had also committed themselves during the 1970 election to negotiate toward Community membership. This similarity among the three parties posed great problems for the normal constitutional procedure through which the People expressed their opinion by their vote: "The electorate, it appeared, would have no voice in what seemed to many the most important constitutional issue of the century, involving as it did the permanent transfer of legislative powers, including the power to tax, away from Westminster."100

On June 5, 1975, the People of the U.K. gave their full-hearted consent to the entry into the $\mathrm{EC}$, with $67.2 \%$ of those voting in the referendum approving U.K. membership. ${ }^{101}$ In order to maintain the theoretical sovereignty of Parliament, the referendum bill was legally only consultative. "The Government will be bound by its result, but Parliament, of course, cannot be bound by it," Edward Short said when offering the referendum bill in the Commons. ${ }^{102}$

The 1975 referendum showed once again that there were times when Parliament felt uncomfortable taking a major constitutional step without directly consulting the People. The Blackstonian myth of indefeasible parliamentary sovereignty had been shattered. By its actions, Parliament had admitted that it could not govern the country without at certain times turning directly to the People for their consent. In May 1970, Edward Heath, then a member of Parliament, had boasted that a referendum was unnecessary since "Parliament can judge completely as to whether it is in the interests of the country to go into the Common Market or not." 103 The fact that the referendum was held showed that Parliament itself admitted that it was not as competent as Heath had suggested.

Although at the time the EC referendum was said to be a unique event-one that would never occur again ${ }^{104}$-four years later, Parliament again turned to the referendum device to obtain popular approval of a major shift in the locus of power.

99. European Communities Act, 1972, ch. 68 (U.K.).

100. BOGDANOR, supra note 9 , at 38 .

101. Id. at 41.

102. 888 PARL. DEB., H.C. (5th ser.) 292-93 (I975).

103. ROgER JOWELl \& GERALD HOINVILLE, BRITAiN INTO EUROPE 113 (1976).

104. BOGDANOR, supra note 9 , at 47. 


\section{The Scotland and Wales Devolution Referenda}

In its October 1974 election manifesto, the Labour Party pledged itself to the devolution of power to directly elected assemblies in Scotland and Wales. The WeIsh Labour Party argued that victory in the general election had given the government a mandate to enact its election platform and claimed that a referendum was therefore unnecessary. Yet in order to attract enough members of Parliament to support the acts for devolution, Labour Prime Minister Callaghan agreed to hold referenda on the subject in 1979. Opposition was raised to two features of the referenda. Some objected to the rule by which a simple majority of those voting was considered insufficient to affirm the validity of the devolution acts: instead, at least $40 \%$ of the electorate had to vote "yes" in order for the devolution acts to be sustained. ${ }^{105}$ The pro-devolution side described the $40 \%$ rule as "a gerrymandering device, a rigging of the Referendum." ${ }^{106}$ Defenders of the $40 \%$ rule argued that if devolution were to occur, it should be affirmed by the people conclusively, something the $40 \%$ rule would guarantee.

Others objected to the fact that the referenda were restricted to the people of Scotland and Wales alone, rather than made open to the entire U.K. electorate, all of whom would be affected by the results. This decision was defended on the grounds that if the entire U.K. voted, "an intolerable situation would be created if Scotland and/or Wales voted in favour of the Bill, but was overruled by an English majority."107

In Wales on March 1,1979, devolution suffered a striking defeat. With a turnout of $58.3 \%$ of the electorate in Wales, $20.3 \%$ of those voting supported the Wales Act, and $79.7 \%$ supported repeal. ${ }^{108}$ In Scotland on the same day, however, the results were mixed. A bare majority, 51.6\%, of those voting (32.9\% of the electorate) supported devolution through the Scotland Act, and a bare minority, $48.4 \%$, of those voting (30.8\% of the electorate) opposed devolution. ${ }^{109}$ Though there was a majority of votes in favor of devolution, the requisite $40 \%$ of the electorate had not voted "yes." Parliament repealed both the Scotland and Wales Acts following the referenda even though the referenda were legally only advisory, not binding. ${ }^{110}$

Given the results of the referenda, parties could no longer claim that going to the people for their direct assent on a proposition was unnecessary because the people could express their wishes in a general election. The fact that Labour

105. Scotland Act, 1978, ch. 51, § 85(2) (U.K.); Wales Act, 1978, ch. 52, § 80(2) (U.K.).

106. John Bochel et al., The Background to the Referendim, in THE REFERENDUM EXPERIENCE: SCOTLAND 1979, at 1, 8 (John Bochel et al. eds., 1981).

107. BOGDANOR, supra note 9 , at $50-51$.

108. Id. at 51 .

109. Id. at 57.

110. The Scotland Act 1978 (Repeal) Order, S.I. 1979, No. 928; The Wales Act 1978 (Repeal) Order, S.I. 1979, No. 933. 
won the 1974 general election on a platform which included devolution ${ }^{111}$ did not mean that the electorate would, on consideration, support devolution. "The presumption was," Bogdanor wrote, "that [the items in a winning party's election program] had all been endorsed by the electorate. But the devastating defeat of the Wales Act in the 1979 referendum was to show that this presumption was without foundation." 112 Referenda were necessary to obtain the true, considered opinion of the electorate.

\section{Establishing Constitutional Conventions}

Are these precedents sufficient to establish the existence of a constitutional convention requiring the submission of at least certain categories of constitutional amendments to the People? In Ivor Jennings' account, the creation of a convention depends on the answers to the following questions: "[F]irst, what are the precedents; second[], did the actors in the precedents believe that they were bound by a rule; and third[], is there a reason for the rule?"113

The 1970's referenda provide clear precedents for a referendum on constitutional issues involving the transfer of parliamentary power. The Northern Ireland Border Poll involved the transfer of control over Northern Ireland from London to Dublin; the EC referendum involved an effective transfer of power to European Community bodies; and the Scotland and Wales referenda involved the transfer of certain powers to new regional assemblies. An entrenched bill of rights that could only be changed with the direct assent of the People would also require the effective transfer of power from Westminster to the courts, and ultimately, to the People.

Though in the 1970's referenda Parliament had shown that it felt it was prudent to refer directly to the People on constitutional issues, whether the actors in these cases felt bound by a rule remains uncertain. On the one hand, there were certainly many who claimed that the contemplated constitutional change would be illegitimate without the directly obtained support of the People. There were, on the other hand, also political motives for parliamentary support for referenda. Political motives, of course, are not inconsistent with a feeling of obligation: observance of constitutional conventions may rest at bottom on such political motives. Jennings, for example, argues that conventions are obeyed "because of the political difficulties which follow if they are not ...."114 It is not clear whether legislators would feel bound by political

111. In the general election of October $1974,75.8 \%$ of the Welsh vote had gone to three parties, including Labour, that supported devolution in their manifestos. BOGDANOR, supra note 9, at 52 .

112. Id. at 49.

113. W. IVOR JENNINGS, THE LAW AND THE CONSTITUTION 136 (5th ed. 1959); see also GEOFFREY MARSHALL, CONSTITUTIONAL CONVENTIONS 10 (1984). Jennings' criteria for determining the existence of constitutional conventions were accepted by the Canadian Supreme Court in Reference re. Amendments of the Constitution of Canada (Nos. 1, 2, and 3), [1981] 1 S.C.R. 753, 888 (Can.).

114. JeNNINGS, supra note 113 , at 134. 
pressures to hold a referendum on the enactment of a bill of rights. ${ }^{115}$

Is there a reason for a rule requiring referral to the People for higher lawmaking? Yes: it furthers the basic purpose of constitutional conventions, which is to ensure that the People remain the political sovereign. ${ }^{116}$ Like the convention on the dissolution of the Parliament, ${ }^{117}$ a convention on constitutional referenda would require turning to the People for their final word in order "to produce harmony between the legal and the political sovereign power," 118 that is, between the Parliament and the People. A convention requiring that Parliament consult the People on certain constitutional transfers of power would be consistent with the principles of democracy.

\section{CONCLUSION}

Recent constitutional theory and practice in the U.K. suggests that entrenchment of a bill of rights should be achieved through a referendum. While this Note has focused primarily on U.K. sources, its ideas are informed by American constitutional scholarship as well. ${ }^{119}$ Perhaps it is more than mere historical coincidence that constitutional democracies on both sides of the Atlantic endow the People with the power to amend their constitution. Perhaps this right is fundamental to democracy itself.

Modern scholarship on a bill of rights relies too heavily on Parliament for enactment of such a charter. Reliance on a parliamentary act, however, poses two dangers: (1) The judiciary may not enforce such a statutory bill of rights against future contrary acts of Parliament; and (2) if the judiciary does enforce this statutory bill of rights, parliamentary powers will be expanded at the expense of the sovereignty of future generations. Entrenchment is better sought not through parliamentary action, but through a direct appeal to the People.

The entrenchment of a bill of rights involves the creation of higher law. The demands of democracy and the need for judicial enforcement counsel that such higher law be made by the People.

115. Legislators have in the past, however, purported to commit future Parliaments to holding referenda. See Northern Ireland Constitution Act, 1973, ch. 36, $\$ 1$ (Northern Ireland to cease to be part of U.K. only with consent of majority of people of Northern Ireland obtained by referendum); $c f$. Northern Ireland Act, 1974 , ch. $28, \S 2(7)$ (requiring that if Secretary of State orders poll of people of Northern Ireland, poll must conform with requirements of Northern Ireland Constitution Act, 1973).

116. This is Dicey's view of constitutional conventions. See supra note 78 and accompanying text.

117. See Dicey's exposition on the dissolutions of Parliament in DICEY, supra note 5, at 432-38.

118. Id. at 438 .

119. Bruce Ackerman trumpets the virtues of a dualist democracy, in which decisions by the People occupy a higher rank than those made by the government. See ACKERMAN, supra note 30, at 3-33. In another work, Ackerman notes that the U.K. may be evolving towards a two-tier lawmaking system involving the use of referenda. See Bruce A. Ackerman \& Robert E. Charney, Canada at the Constitutional Crossroads, 34 U. TORONTO L.J. 117, 118 n.7 (1984). Akhil Amar believes that a majority of the People must always be able to amend the Constitution in order to prevent domination by the decisions of earlier generations. See Amar, supra note 95, at 1072-73. 